\title{
Properties of Vitamin E-Deficient Erythrocytes following Peroxidant Injury
}

\author{
BERTRAM LUBIN AND DANNY CHIU ${ }^{(33)}$ \\ Bruce Lyon Memorial Research Laboratory and Department of Hematology/Oncology, Children's Hospital Medical \\ Center, Oakland, California, USA
}

\begin{abstract}
Summary
Several membrane properties of vitamin E-deficient and normal erythrocytes were studied after incubation of these cells with hydrogen peroxide. Measurements of mean corpuscular volume, cation permeability, membrane $\mathrm{Na}^{+}, \mathrm{K}^{+}$ATPase activity, red cell filterability through $5 \mu$ millipore filters, and membrane protein pattern on sodium dodecyle sulfate-gel electrophoresis revealed marked alterations before lysis. Vitamin $\mathrm{E}$ sufficient cells were unaffected by a similar incubation with hydrogen peroxide. We speculate that the changes in membrane function, which follow peroxidant injury, contribute to the shortened red cell survival in the vitamin $E$ deficient state.
\end{abstract}

An anemia secondary to vitamin E deficiency has long been recognized in premature infants (20). Dietary supplementation with vitamin E prevents the development of this anemia. Red cell chromium survival studies have demonstrated a shortened life span for red cells from vitamin E-deficient premature infants (22); however, the exact cause of this shortened red cell survival is poorly understood.

In light of the antioxidant role of vitamin $E$ in biologic tissues (28), it is generally believed that the shortened erythrocyte survival in vitamin E-deficient premature infants is the result of membrane damage secondary to enhanced lipid peroxidation. Indeed, many changes in the membrane of vitamin E-deficient red cells after peroxidant injury have been reported. Among these changes is the prelytic loss of phosphatidylethanolamine $(9,10)$. This observation is consistent with the fact that phosphatidylethanolamine contains a high concentration of polyunsaturated fatty acids and these fatty acids are liable to lipid peroxidation in the absence of appropriate amount of antioxidant. Furthermore, Lubin et al. (16) have demonstrated that hydrogen peroxide stimulated the incorporation of fatty acid into vitamin E-deficient red cells but had no effect on the incorporation of fatty acid into normal red cells. They suggested that peroxidant injury to vitamin E-deficient red cells stimulates a membrane repair process. Because products of lipid peroxidation can react with sulfhydryl and/or amino groups of proteins $(2,14,25)$, peroxidative process initiated in the membrane lipid moiety will inevitably lead to damage in membrane proteins.

Although Stocks and Dormandy (27) clearly demonstrated that peroxidant injury to red cells can lead to eventual hemolysis, changes in cellular properties before hemolysis after oxidative damage have not been carefully studied. This paper reports changes in the cellular properties of vitamin E-deficient human erythrocytes as a consequence of $\mathrm{H}_{2} \mathrm{O}_{2}$-induced peroxidant injury in vitro. Among the cellular properties reported in this paper are membrane protein alterations, red cell size, cation permeability, membrane $\mathrm{Na}^{+}, \mathrm{K}^{+}$ATPase activity, and red cell filterability through millipore filters.

\section{MATERIALS AND METHODS}

Cell preparation. Heparinized blood was obtained with informed consent of the parents from premature infants whose birth weight was less than $1500 \mathrm{~g}$. The red cells were washed three times with Krebs Henseleit Buffer (KHB) pH 7.4, and residual leukocytes and platelets were removed. The peroxide hemolysis test, performed by previously reported methods (24), was positive in all patients studied, and \% hemolysis ranged from 60-100\%. Plasma vitamin $E$ level of all vitamin E-deficient premature infants was below $0.5 \mathrm{mg} / \mathrm{dl}$. Control red cells were obtained from premature infants who were receiving supplemental vitamin $\mathrm{E}$ and had a peroxide hemolysis value of less than $5 \%$. All experiments were performed in duplicate. The results indicate the mean values of two individual patients used for each experiment.

Red cell volume distribution. A 4\% suspension of red cells was incubated with an equal volume of $1 \%$ hydrogen peroxide (final concentration, $147 \mathrm{mM}$ ) in a $30-\mathrm{ml}$ beaker. A Coulter electrode connected to a digital plotter recorded the erythrocyte volume distribution before peroxide addition and at 1 -min intervals during the subsequent incubation with hydrogen peroxide. The controls consisted of vitamin E-deficient cells incubated in the presence of equal volumes of KHB and normal cells incubated with and without hydrogen peroxide.

Potassium efflux. Red cells previously washed in KHB were incubated for $2 \mathrm{~h}$ at $37^{\circ} \mathrm{C}$ in isotonic saline containing $50 \mu \mathrm{Ci}$ of $\left[{ }^{42} \mathrm{~K}\right]$ at a hematocrit of $30 \%$. Unincorporated $\left[{ }^{42} \mathrm{~K}\right]$ was removed by three washes in ten volumes of $\mathrm{KHB}$ at $37^{\circ} \mathrm{C}$. The cells were then resuspended to a hematocrit of $4 \%$ and were incubated in separate tubes for each time-sample with an equal volume of $1 \%$ hydrogen peroxide in KHB. An initial sample was reserved to determine the total $\left[{ }^{42} \mathrm{~K}\right]$ incorporated. At 5-min intervals, $0.1 \mathrm{ml}$ of a saturated solution of thymol was added to the successive incubation mixtures to inhibit further peroxidation (31). The suspensions were centrifuged at $5000 \mathrm{rpm}$ for $5 \mathrm{~min}$ and the supernatant removed. The radioactivity in aliquots of the supernatant was determined and expressed as a percentage of the total radioactivity incorporated. Percent hemolysis was determined on similar aliquots taken at the same time. The initial cell concentration of $\left[{ }^{42} \mathrm{~K}\right]$ in the reserved cells was determined by counting aliquots of the washed cells that had been dissolved in Beuhler's reagent (1).

Filterability. Cells were incubated with hydrogen peroxide as described above. After 15 min of incubation, concentrated thymol was added to the incubation mixture. After the separation of cells from the supernatant, cells were washed twice with KHB and resuspended to a $2 \%$ hematocrit in KHB. The mean corpuscular volume was determined for each sample. Cells were then filtered through a $5 \mu$ millipore filter at $37^{\circ} \mathrm{C}$ at a pressure of $20 \mathrm{mmHg}$ as reported by Schmid-Schonbein et al. (26). The time required for $2 \mathrm{ml}$ of red cell suspension to pass the filter was recorded and was used to calculate the rate of filtration.

Sodium dodecyl sulfate-polycrylamide gel electrophoresis. Ghosts were prepared by the method of Dodge et al. (4) from cells which had been incubated with or without hydrogen peroxide as described above. To carry out SDS-polyacrylamide gel electrophoresis of membrane proteins, aliquots of ghost preparations were treated with equal volumes of $20 \mathrm{mM}$ Tris buffer containing $2 \%$ SDS, $20 \%$ sucrose, $2 \mathrm{mM}$ EDTA and $\mathrm{I} \mathrm{ml}$ of $1 \%$ phenol red, $\mathrm{pH}$ 7.9 , for $30 \mathrm{~min}$ at $37^{\circ} \mathrm{C}$. Upon completion of incubation, an 
aliquot of approximately $30 \lambda$ of ghost incubation mixture containing exactly $40 \mu \mathrm{g}$ of membrane proteins were loaded onto a 4\% Biophore-gels (BioRad, Richmond, CA). After completion of electrophoresis, gels were fixed with isopropanol and stained with Coomassie blue dye by the method of Fishbein (5). Membrane protein concentration of different ghost preparations was determined by the Method of Lowry et al. (15).

Membrane $\mathrm{Na}^{+}, \mathrm{K}^{+}$ATPase activity. Because the activity of $\mathrm{Na}^{+}, \mathrm{K}^{+}$ATPase is completely abolished by $0.2 \mathrm{mM}$ ouabain, the activity of this enzyme was determined as the difference between assays in the presence and the absence of ouabain. In our assay procedure, $0.5 \mathrm{mg} / \mathrm{ml}$ of membrane protein was suspended in 3 $\mathrm{ml}$ of $50 \mathrm{mM}$ Tris buffer ( $\mathrm{pH} 7.4$ ) containing $50 \mathrm{mM} \mathrm{NaCl}, 120$ $\mathrm{mM} \mathrm{KCl}, 5 \mathrm{mM} \mathrm{MgCl}$, with and without $0.2 \mathrm{mM}$ Ouabain. At timed intervals during the $37^{\circ} \mathrm{C}$ incubation, aliquots of the reaction mixture were taken, mixed with $6 \%$ trichloroacetic acid and subsequently assayed for phosphorus in the supernatant.

\section{RESULTS}

Corpuscular volume distribution. Figure 1 shows the sequential changes in corpuscular volume distribution in vitamin E-deficient red cells after incubation with hydrogen peroxide. The size distribution in these cells rapidly decreased within the first 5 min after the addition of hydrogen peroxide, and then progressively increased during further incubation until lysis occurred. The same cells incubated in buffer without $\mathrm{H}_{2} \mathrm{O}_{2}$ showed no change in volume distribution. Normal cells, not shown in the graph, were not altered in volume distribution during the incubation with or without hydrogen peroxide in KHB.

Potassium efflux. The loss of $\left[{ }^{42} \mathrm{~K}\right]$ from vitamin E-deficient red cells to the incubation medium is graphically shown in Figure 2. Potassium permeability was markedly increased immediately upon the addition of hydrogen peroxide. Hemoglobin release was not noted until $30 \mathrm{~min}$ after the addition of hydrogen peroxide, at which time $20 \%$ of the incorporated $\left[{ }^{42} \mathrm{~K}\right]$ had been lost to the medium. In the absence of hydrogen peroxide, no loss of $\left[{ }^{42} \mathrm{~K}\right]$ was observed in these cells. Furthermore, hydrogen peroxide did not increase the potassium permeability of normal cells.

Filterability. Red cell filterability was markedly decreased in the vitamin E-deficient cells after incubation with hydrogen peroxide for $15 \mathrm{~min}$. (Table 1). In contrast, when normal red cells were similarly incubated, they showed no change in filterability. The 15 min-incubation period was chosen because at this time the mean corpuscular volume of the vitamin E-deficient cells incubated with hydrogen peroxide was not significantly different from the mean corpuscular volume of the vitamin E-deficient cells incubated in KHB (101-102 $\mu^{3}$, respectively; also see Fig. 1). Filtration rates for vitamin E-deficient cells in KHB without

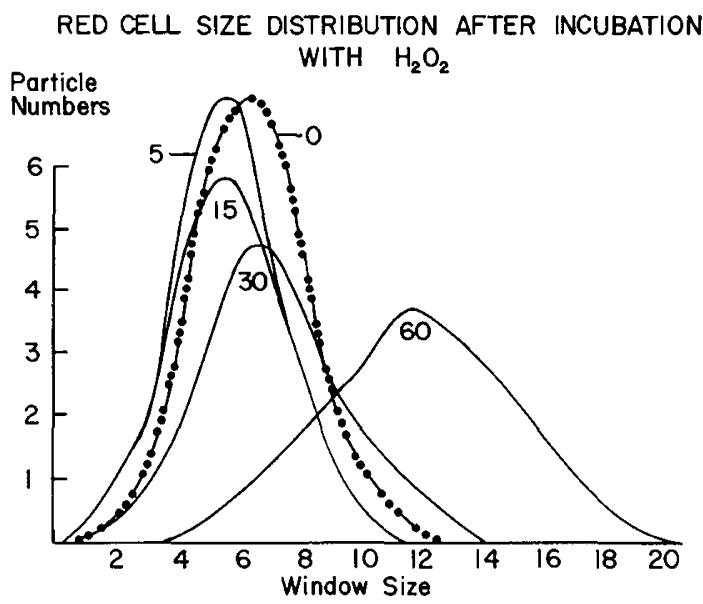

Fig. 1. Red cell size distribution after incubation with $\mathrm{H}_{2} \mathrm{O}_{2}$. The size distribution of vitamin E-deficient red cell before incubation with $\mathrm{H}_{2} \mathrm{O}_{2}$ (0 time) and at 5, 15, 30, and 60 min intervals after incubation with $\mathrm{H}_{2} \mathrm{O}_{2}$ was recorded by a Coulter electrode connected to a digital plotter.

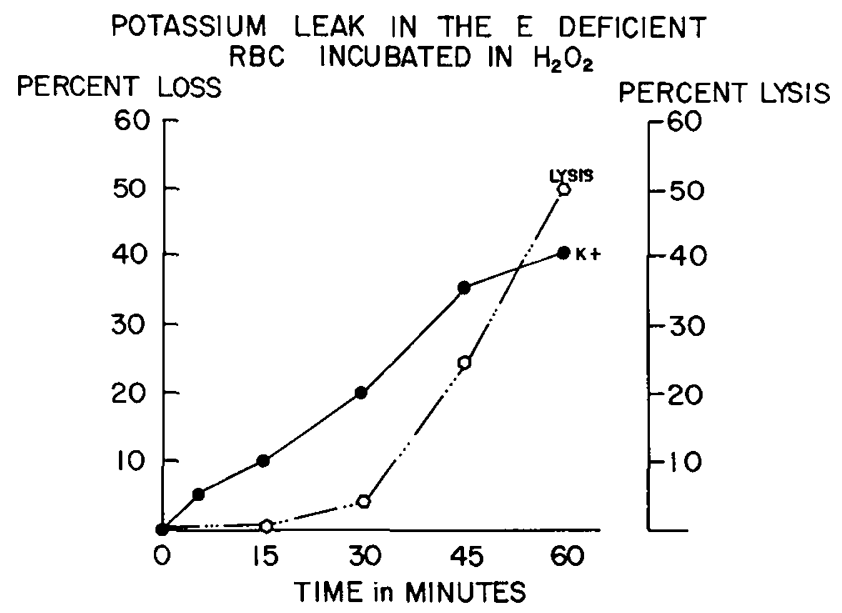

Fig. 2. Effect of $\mathrm{H}_{2} \mathrm{O}_{2}$ on potassium permeability and hemolysis of vitamin E-deficient red cells. Potassium leakage of $\mathrm{H}_{2} \mathrm{O}_{2}$-treated vitamin E-deficient red cells was monitored by measuring the release of $\left[{ }^{42} \mathrm{~K}\right]$ into the incubation medium at different time intervals after the addition of $\mathrm{H}_{2} \mathrm{O}_{2}$. The $\left[{ }^{42} \mathrm{~K}\right]$ was first incorporated into red cells before incubation with $\mathrm{H}_{2} \mathrm{O}_{2}$. Hemolysis was monitored by the release of hemoglobin from red cells into the incubation medium.

Table 1. Effect of $\mathrm{H}_{2} \mathrm{O}_{2}$ on red cell filterability

\begin{tabular}{lc}
\hline \multicolumn{1}{c}{ Red blood cell samples } & Rate of filtration $\left(\mathrm{mm}^{3} / \mathrm{sec}\right)$ \\
\hline Normal (4) & $122 \pm 6.5^{2}$ \\
$\mathrm{H}_{2} \mathrm{O}_{2}$-treated normal (4) & $149 \pm 8.2$ \\
Vitamin E-deficient (4) & $142 \pm 7.9$ \\
$\mathrm{H}_{2} \mathrm{O}_{2}$-treated vitamin E-deficient (4) & $49 \pm 6.3$ \\
\hline
\end{tabular}

${ }^{\prime}$ Number in parenthesis indicates number of experiments.

${ }^{2}$ Mean \pm S.E.

hydrogen peroxide were not significantly different from those of normal cells in KHB with or without hydrogen peroxide.

Membrane protein pattern on SDS-polyacrylamide gel electrophoresis. Figure $3 \mathrm{~A}$ shows the electrophoresis patterns of the membrane proteins from vitamin E-deficient red cells on $4 \%$ polyacrylamide gels in SDS. The membrane protein pattern of vitamin E-deficient red cells (gel E and F) was similar to that of normal red cells (not shown in this Fig.); however, after exposure to hydrogen peroxide, vitamin E-deficient red cells exhibited abnormal membrane protein patterns, particularly expressed by the formation of high molecular weight aggregates (gels A-D). Furthermore, densitometry scanning of these gels (Fig. 3B) clearly demonstrated diminished quantities of spectrin (bands 1 and 2) in vitamin E-deficient red cells exposed to hydrogen peroxide as compared to the same cells that were not exposed to hydrogen peroxide. Incubation of normal red cells with hydrogen peroxide did not alter the membrane protein pattern of these cells.

Membrane $\mathrm{Na}^{+}, \mathrm{K}^{+}$ATPase activity. Figure 4 shows the influence of hydrogen peroxide on membrane $\mathrm{Na}^{+}, \mathrm{K}^{+}$activity in vitamin E-deficient and normal red cells. The enzyme activity was decreased by $60 \%$ after vitamin E-deficient red cells were incubated with hydrogen peroxide. In contrast, the enzyme activity was unaffected in normal red cells by a similar incubation with hydrogen peroxide. Furthermore, the initial enzyme activity in vitamin E-deficient red cells was similar to that in normal red cells.

\section{DISCUSSION}

The results of these studies demonstrate the diffuse membrane injury in vitamin E-deficient red cells induced by hydrogen peroxide. Peroxidative reactions can lead to membrane damage followed by alteration in cellular properties and eventual cell lysis (3). Although our in vitro incubation mixture contained a nonphysiologic concentration of hydrogen peroxide, the continuous production of hydrogen peroxide in vivo as a consequence of 
A

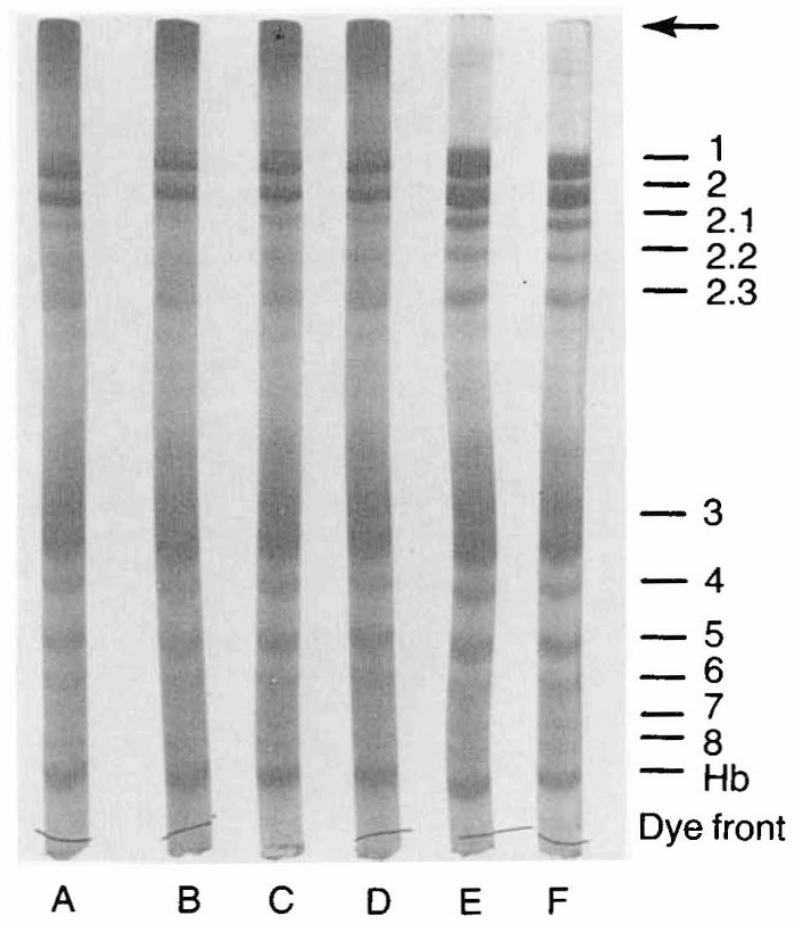

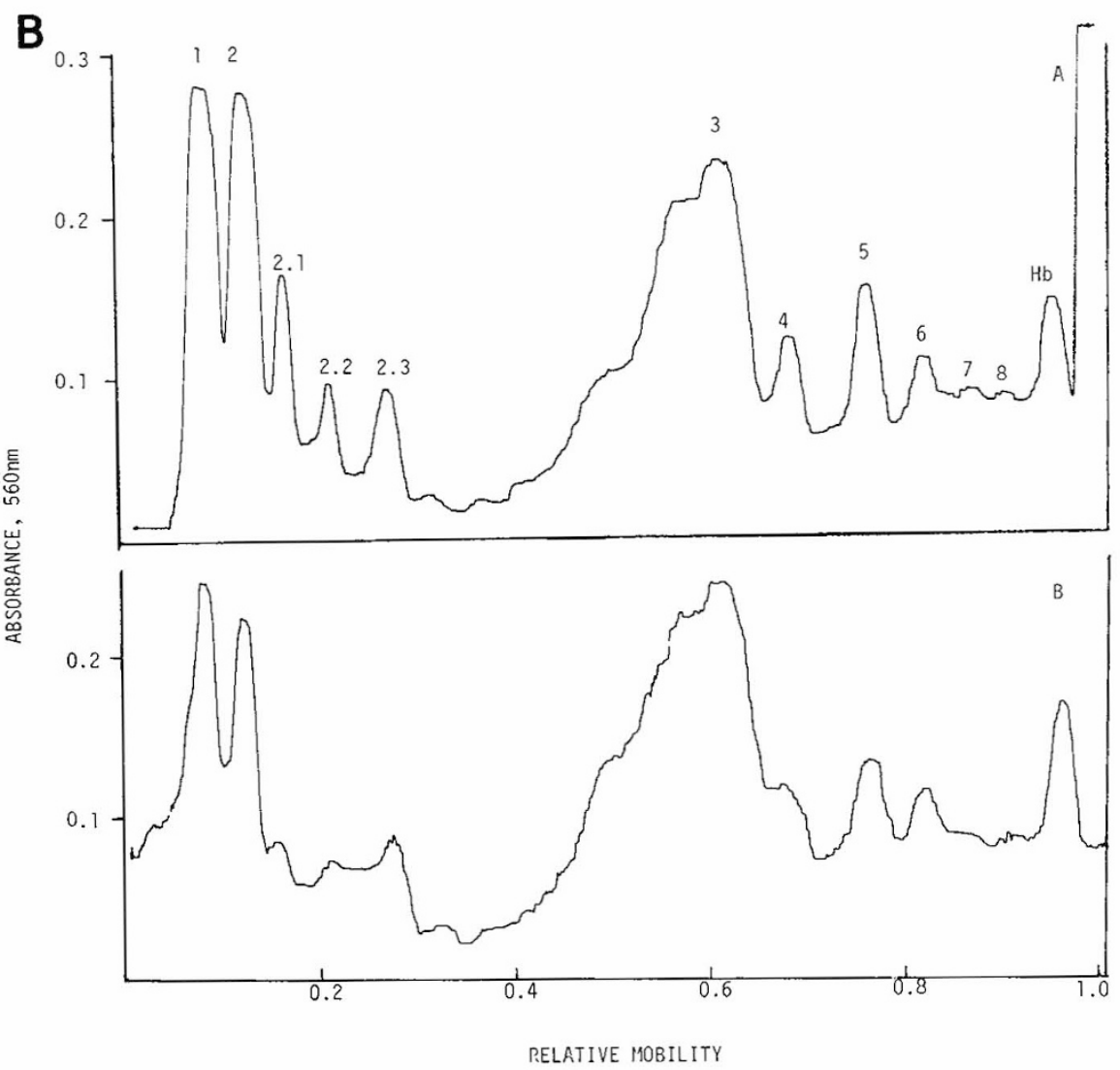

Fig. 3. (Left hand panel) alteration of membrane proteins of vitamin E-deficient red cell following $\mathrm{H}_{2} \mathrm{O}_{2}$ incubation. Membrane proteins were separated by electrophoresis in $4 \%$ polyacrylamide gel containing $1 \%$ sodium dodecyl sulfate and stained by Coomassie blue. All gels contained exactly $40 \mu \mathrm{g}$ of membrane proteins. Gels A through D shows the membrane protein pattern of vitamin E-deficient red cell following incubation with $\mathrm{H}_{2} \mathrm{O}_{2}$. Arrow indicates the formation of large molecular weight membrane protein aggregates on $\mathrm{H}_{2} \mathrm{O}_{2}$ treated vitamin E-deficient red cells. The aggregates were not present in $\mathrm{H}_{2} \mathrm{O}_{2}$-treated vitamin E-sufficient red cells. Gels $\mathrm{E}$ and $\mathrm{F}$ shows the membrane protein pattern of vitamin E-deficient red cells without $\mathrm{H}_{2} \mathrm{O}_{2}$ treatment. Bands 1 and 2 are spectrin. (Right hand panel) densitometery scanning of membrane protein patterns on sodium dodecyl sulfate-polyacrylamide gels. Panel $A$ shows the membrane protein pattern of $\mathrm{H}_{2} \mathrm{O}_{2}$-treated vitamin E-sufficient red cells which correspond to gel E of the figure's left hand panel. Panel B shows diminished spectrin content (bands 1 and 2) of $\mathrm{H}_{2} \mathrm{O}_{2}$-treated vitamin E-deficient red cells which corresponds to gel A of the figure's left hand panel. 


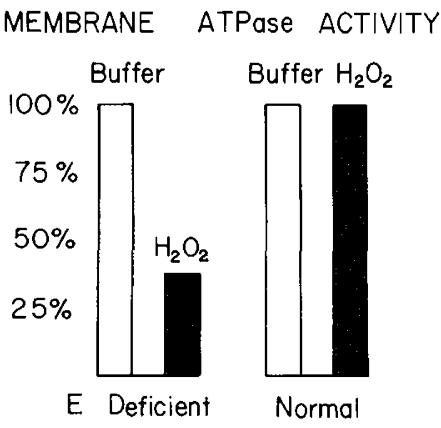

Fig. 4. Decreased membrane $\mathrm{Na}^{+}, \mathrm{K}^{+}$ATPase activity of vitamin Edeficient red cells after incubation with $\mathrm{H}_{2} \mathrm{O}_{2}$. In this assay procedure, membrane protein $(0.5 \mathrm{mg} / \mathrm{ml})$ was suspended in $3 \mathrm{ml}$ of $50 \mathrm{mM}$ tris buffer ( $\mathrm{pH}$ 7.4) containing $50 \mathrm{mM} \mathrm{NaCl}, 120 \mathrm{mM} \mathrm{KCl}, 5 \mathrm{mM} \mathrm{MgCl}_{2}$, with and without $0.2 \mathrm{mM}$ quabain. At approximate time intervals, the release of phosphate was assayed. $\mathrm{H}_{2} \mathrm{O}_{2}$ treatment decreased the ATPase activity in vitamin E-deficient red cells but the enzyme activity was not affected in normal red cells.

normal red cell metabolism such as the conversion of oxyhemoglobin to methemoglobin (18) may produce subtle membrane damage of physiologic significance. Furthermore, our in vitro design may mimic an in vivo condition in which red cells are exposed to a sudden burst of oxidative stress such as that which occurs after treatment with oxidant drugs $(6,7)$. It has also been shown that stimulated human neutrophils generate superoxide radicals which can lyse normal human erythrocyte (29).

The exact mechanism underlying the hydrogen peroxide-induced alterations in cellular properties of vitamin E-deficient cells is not clear; however, our results together with those available in the literature strongly suggest that membrane alterations are initiated via a lipid peroxidation scheme. Kesner et al. (12) have demonstrated that peroxidized phospholipids are potent inhibitors of human erythrocyte membrane $\mathrm{Na}^{+}, \mathrm{K}^{+}$ATPase. Because phostidyl serine is rich in polyunsaturated acyl side chains, the finding of Roelofsen and van Deenen (23) indicating that phosphatidyl serine plays an important role in monitoring ATPase activity may explain why $\mathrm{Na}^{+}, \mathrm{K}^{+}$ATPase is very susceptible to oxidative insult (Fig. 4).

Alternatively, the changes in membrane permeability may represent a direct toxic effect of peroxidation on membrane integrity. It has long been recognized that changes in membrane fatty acid composition contribute to alteration of membrane permeability in both artificial membranes (19) and intact red cells (13). Changes in membrane permeability were closely associated with a change in cell volume and were subsequently followed by gradual colloidal lysis. Similar changes have been observed in mitochondrial and lysosomal membranes as a consequence of peroxidant injury (30).

It must be pointed out that multiple factors determine the degree of hemolysis seen in the vitamin E-deficient premature infants. Infants fed formulas containing an elevated concentration of polyunsaturated fatty acid and decreased concentration of vitamin $\mathrm{E}$ have a greater incidence of hemolysis than those fed breast milk containing a more appropriate ratio of vitamin $\mathrm{E}$ per mole of polyunsaturated fatty acids (PUFA) (22). Moreover, exposure to oxygen at high pressure (11) or the addition of iron have also been demonstrated to accentuate the hemolytic process in the vitamin E deficient state (17). Because both oxygen and iron (3) play an important role in lipid peroxidation, these findings are consistent with the hypothesis that hemolytic anemia in vitamin E-deficient premature infants is the result of erythrocyte membrane damage secondary to enhanced lipid peroxidation.

Peroxidant injury initiated in the lipid components of the membrane can easily be transmitted to neighboring proteins. Sulfhydryl groups in the proteins are extremely susceptible to free radical attack $(14,25)$. Among the membrane proteins, spectrin has been shown to be particularly susceptible to oxidant injury $(8$,
21), perhaps due to the proximity of exposed spectrin sulfhydryls within the membrane. Our results (Fig. $3 a$ and b) also demonstrate that spectrin (bands 1 and 2) is more susceptible to oxidant injury than other membrane proteins. Formation of spectrin aggregates as a result of oxidative insult may explain, in part, the reduced filterability seen in hydrogen peroxide-treated vitamin E-deficient cells (Table 1).

Taken together, our data suggest that several changes observed in membrane structure and function after oxidant injury in vitro could explain the shortened red cell survival observed in the vitamin E-deficient state. Evidence is accumulating to indicate that peroxidative reactions continually take place in human erythrocytes and these peroxidative reactions are potentially deleterious to the red cells. Fortunately, the potential adverse effects of these reactions can be minimized by the normal amount of antioxidant reserve in red cells under most circumstances; however, decreased antioxidant reserve as in the case of vitamin E deficiency, or excess oxidant stress, will lead to irreversible membrane damage and shortened red cell survival.

\section{REFERENCES AND NOTES}

1. Beutler, D. R.: A simple scintillating technique for assaying ${ }^{14} \mathrm{CO}_{2}$ in a Warburg flask. Anal. Biochem., 4: 373 (1962).

2. Chio, K. S. and Tappel, A. L.: Inactivation of ribonuclease and other enzymes by peroxidizing lipids and by malonaldehyde. Biochemistry, 8: 2827 (1969).

3. Chiu, D.. Lubin, B., and Shohet, S. B.: Peroxidative reactions in red cell biology in Free radicals in biology, Vol. V, W. Pryor, Ed., Academic Press, N.Y., N.Y. pp 115-160. (1982)

4. Dodge, J. T., Mitchell, C., and Hanahan, D.: The preparation and chemical characteristics of hemoglobin-free ghosts of human erythrocytes. Arch. Biochem. Biophys., 100: 119 (1963).

5. Fishbein, W. N.: Quantitative densitometry of $1-5 \mu \mathrm{g}$ protein in acrylamide gel slabs with Coomassie blue. Anal. Biochem., 46: 388 (1972).

6. Goldstein, B. D. and McDonagh, E. M.: Spectrofluorescent detection of in vivo red cell lipid peroxidation in patients treated with diaminodiphenylsulfone. J. Clin. Invest.. 57: 1302 (1976).

7. Goodman, J. and Hochstein, P.: Generation of free radicals and lipid peroxidation by redox cycling of adriamycin and daunomycin. Biochem. Biophys. Res. Comm., 77: 797 (1977)

8. Haest, C. W. M., Plass, G., Kamp, D., and Deuticke. B.: Spectrin as a stabilizer of the phospholipid asymmetry in the human erythrocyte membrane. Biochim. Biophys. Acta, 509: 21 (1978).

9. Heikkila, R. E., Mezick, J. A., and Cornwell, D. G.: Destruction of specific membrane phospholipids during peroxidative hemolysis of vitamin $E$ deficient erythrocytes. Physiol. Chem. Physics, 3: 93 (1971).

10. Jacob, H. S. and Lux, S. E.: Degradation of membrane phospholipids and thiols in peroxide hemolysis: studies in vitamin E deficiency. Blood 32: 549 (1968).

11. Kann, H. E., Jr., Mengel, C. E., Smith, W., and Horton, B.: Oxygen Toxicity and Vitamin E. Aerospace Med., 35: 840 (1964).

12. Kesner, L., Kindya, R. J., and Chan, P. C.: Inhibition of erythrocyte membrane $\left(\mathrm{Na}^{+}, \mathrm{K}^{+}\right)$-activated ATPhase by Ozone-treated phospholipids. J. Biol. Chem.. 254: 2705 (1979)

13. Kogl, F.. DeGrier, J., Mulder, I., and Van Deenen, L. L. M.: Metabolism and functions of phosphatides: specific fatty acid composition of the red cell membranes. Biochim. Biophys. Acta, 43: 95 (1960).

14. Lewis, S. E. and Wills, E. D.: The destruction of -SH groups of proteins and amino acids by peroxides of unsaturated fatty acids. Biochem. Pharmacol., 11 : 901 (1962)

15. Lowry, O. H., Rosebrough, N. J., Farr, A. F., and Randall, R. J.: Protein measurement with the folin phenal reagent. J. Biol. Chem., 193: 265 (195I).

16. Lubin, B. H., Shohet, S. B., and Nathan, D. G.: Changes in fatty acid metabolism after erythrocyte peroxidation: Stimulation of a membrane repair process. J. Clin. Invest., 51: 338 (1972).

17. Melhorn, D. K. and Gross, S.: Vitamin E dependent anemia in the premature infant. I. Effect of large doses of medicinal iron. J. Pediatr., 79: 569 (1971).

18. Misra, H. P. and Fridovich. I.: The generation of superoxide radical during the autoxidation of hemoglobin. J. Biol. Chem., 247: 6960 (1972).

19. Moore, J. L., Richardson, T., and DeLuca, H. F.: Essential fatty acids and ionic permeability of lecithin membranes. Chem. Phys. Lipids, 3: 39 (1968).

20. Oski, F. A. and Barness, L. A.: Vitamin E deficiency: a previously unrecognized cause of hemolytic anemia in the premature infant. J. Pediatr., 70: 211 (1967)

21. Palek, J. and Liu. S. C.: Dependence of spectrin organization in red blood cell membrane on cell metabolism implications for control of red cell shape, deformability, and surface area. Semin. in Hemat. 14: 74 (1979).

22. Ritchie, J. H., Fish, M. B., McMasters, V., and Grossman, M.: Edema and hemolytic anemia in premature infants. N. Engl. J. Med., 279: 1185 (1968).

23. Roelofsen, B. and vanDeenen, L. L. M.: Lipid requirement of membrane-bound ATPase. Studies on human erythrocyte ghosts. Eur. J. Biochem., 40: 245 (1973).

24. Rose, C. S. and Gyorgy, P.: Specificity of the hemolytic reaction in vitamin $E$ deficient erythrocytes, Am. J. Physiol., 168: 414 (1952).

25. Roubal. W. T. and Tappel, A. L.: Damage to proteins, enzymes, and amino acids 
by peroxidizing lipids. Arch. Biochem. Biophys., /13: 5 (1966).

26. Schmid-Schonbein, H., Wells, R., and Goldstone, J.: Influence of deformability of human red cells upon blood viscosity. Circ. Res. $X X V$ : 131 (1969).

27. Stocks, J. and Dormandy, T. L.: The autoxidation of human red cell lipids induced by hydrogen peroxide. Brit. J. Haematology, 20: 95 (1971).

28. Tappel, A. L.: Vitamin E as the biological lipid antioxidant. Vitamins Hormones, 20: 493 (1962).

29. Weiss, S. J.: The role of superoxide in the destruction of erythrocyte targets by human neutrophils. J. Biol. Chem., 255: 9912 (1980).

30. Wills, E. D. and Wilkinson, A. E.: Release of enzymes from lysosomes by irradiation and the relation of lipid peroxide formation to enzyme release. Biochem. J., 99: 657 (1966).
31. Youkin, S., Oski, F. A., and Barness, L. A.: Observations on the mechanism of hydrogen peroxide hemolysis test and its reversal with phenols. Am. J. Clin. Nutr.. 24: 7 (1971).

32. The authors are grateful to Dr. Margaret Clark for her critical review of this manuscript.

33. Requests for reprints should be addressed to: Dr. Danny Chiu, Department of Hematology/Oncology, Bruce Lyon Memorial Research Laboratory, Children's Hospital Medical Center, Oakland. California 94609.

34. This research project is in part supported by a grant-in-aid from Hoffman LaRoche Inc.

35. Received for publication December 8, 1981.

36. Accepted for publication April 16, 1982. 